\title{
KOULUTUS, KUSTANNUS VAI INVESTOINTI?
}

\author{
Koulutuksen vaikuttavuus taloustieteellisenä ongelmana
}

\section{Hahuttujen koulutus- ja oppimisvaikutusten aikaansaaminen vaatii pitkän ajan, ja panostekijöiden radikaali muuttaminen säteilee vaikutuksia pitkälle tulevaisuuteen. Näin toteaa Reijo Raivola eritellessään koulutuksen tehokkuutta ja vaikuttavuutta taloustieteen nảkökulmasta. Artikkelin keskeinen käsite on koulutuksen tuotantofunktio. Kirjoittaja näkisi kasvatuksen (oppimisen) tuotantofunktion ja sen avulla koulutuksen tuotantofunktion salojen paljastamisen tehostettua tutkimusta vaativina kohteina.}

Julkishallinnon toiminta- ja budjetointitavat ovat muuttuneet ja muuttumassa voimakkaasti 1990-luvulla. Kun taloudellisella kasvulla ja verokertymien runsauden sarvellakin on rajansa, on herätty todellisuuteen, joka elinkeinoelämän yksityisellä sektorilla on aina ollut itsestäänselvyys.

Jatkuvaksi tarkoitetun pitkäjänteisen toiminnan, ovat sen tavoitteet ja sisältö mitkä tahansa, on oltava taloudellista, tehokasta ja vaikuttavaa. Katsotaan, että näihin päämääriin pääsemiseksi on organisaatioissa toimivilta oikeus vaatia tulosvastuuta. Tuloksellinen toiminta puolestaan palkitaan lisäämällä toiminnan panoksena käytettäviä voimavaroja ja niiden käytön vapautta. Tehotonta ja tuloksetonta toimintaa taas leikataan niin, että vain välttämättömät toimintaedellytykset turvataan jos toiminta yleensä katsotaan lainkaan tarpeelliseksi.
Niillä toimialoilla, joilla tuotoksena ovat konkreettiset hyödykkeet, tavarat tai palvelut, ja joilla toiminnasta kertyvää lisäarvoa voidaan mitata rahalla tai muuten määrällisesti, ajattelumalli toimiikin yleensä hyvin.

Mutta toiminnoissa, joissa tuloksena ovat abstraktiset ja laadulliset, pitkällä aikavälillä ilmenevät muutokset ihmisessä, tuotosta ja sen arvoa on vaikea määritellä budjettikiertojen määräämässä pakkotahdissa. Jotta voimavarojen jakoa keppinä ja porkkanana voitaisiin loogisesti perustella näissäkin tapauksissa, olisi tiedettävä jotakin siitä, miten resurssit toiminnassa muuttuvat tuotoksiksi. Tulosvastuuta voidaan vaatia vain niiltä, jotka voivat vaikuttaa toiminnan tulokseen.

\section{TUOTANTOFUNKTION KÄSITTEESTÄKö KRITEERI?}

Järjestelmän sisäistä taloudellista toimintaa, joka voimassa olevilla hinnoilla ja käytössä olevalla teknologialla muuntaa koulutuksen panostekijät tavoitteiden mukaiseksi kasvatukselliseksi tuotokseksi, kutsutaan koulutuksen tuotantofunktioksi. (Tsang 1988)

Muodostettava lauseke kuvaa sitä, miten on mahdollista saavuttaa maksimaalinen tuotos käyttämällä tehokkaasti resursseja erilaisina yhdistelmävaihtoehtoina. Funktio summaa yksittäiset tekniset riippuvuudet (korrelaatiot) yhdistetyksi lausekkeeksi panos- ja tuotostekijöiden välillä. Käsitteenä se on perustavanlaatuinen koulutuksen hallinnolle ja suunnittelulle.

Jos se loogisesti ja todellisesti on olemassa, tiedetään jotakin prosessista, joka muuntaa panokset tuotokseksi. Jos funktiolauseke tunnetaan, toisin sanoen sen tekijöiden (rahalliset ja määrälliset) 
arvot ovat laskettavissa, hallinto voi ennakoida tuotannon tason, joka annetuilla ehdoilla on teknisesti mahdollista saavuttaa. Tai toisinpäin: paljonko voimavaroja tarvitaan asetetun tavoitetason saavuttamiseksi? Tulosvastuun vaatiminen ja pyrkimys tebokkuuden lisäämiseen edellyttävät tuotantofunktion olemassaoloa ja tuntemista. (ks. Hanushek 1986, Levin 1988, Monk 1989)

\section{Panostekijät}

Panostekijät ovatkin suhteellisen helposti tunnistettavissa: oppilaat, opiskelijat ja opettajat mitattuine valmiuksineen ja lähtötasoineen, laboratoriot, perusmateriaalit, rakennukset kalusteineen, siis kaikki se, jota voitaisiin kutsua oppimisen infrastruktuuriksi. Näille tekijöille voidaan laskea käypä hinta ja muuntaa (diskontata) se kulloisenkin tarkasteluajankohdan käyväksi rahalliseksi arvoksi.

Usein panoskustannukset arvioidaan liian pieniksi, koska mukaan ei lasketa käyttämättä jääneiden vaihtoehtoisten investointimahdollisuuksien aiheuttamia (laskennallisia) menoja (opportunity costs), joista suurin on koulutusajalta ansaitsematta jääneet tulot.

Toisen ongelman muodostaa koulutusjärjestelmän moniportaisuus ja jatkuvuus: edellisen koulutusvaiheen tuotosta käytetään seuraavan vaiheen panoksena.

Mistä alkaen esimerkiksi eri aikuiskoulutusorganisaatioissa tapahtuvan opiskelun kustannukset olisi laskettava mukaan koulutuksen tuottavuutta arvioitaessa (kaiken oppivelvollisuuden jälkeisen koulutuksenko?) ja kuinka pitkälle eteenpäin järjestelmässä kustannukset on kuljetettava laskelmissa mukana? Monille panostekijöille ei myöskään voida laskea kilpailun asettamaa kaupallista (reaalista) hintaa, koska julkinen suljettu sektori toimii monopolina ilman kilpailua tai kilpailee epäaidosti keskenään. Hinnat muodostuvat sopimusteitse tai hallinnollisesti. Vaikea on myös sopia diskonttokoron suuruudesta, jonka avulla muunnetaan koulutuksen hankinta-aikaiset hinnat sen hyödyntämisen aikaiseen hintatasoon inflaatio ja kohtuullinen tuotto muistaen.

\section{Tuotostekijät}

Tulostekijä puolestaan muodostuu kahdesta osasta. Ensinnäkin on välitön kasvatuksellinen tuotos, joka näkyy opiskelijan tiedollisten, asenteellis-sosiaalisten ja toiminnallisten valmiuksien arvonlisänä. Näiden mittaamiseen koulutusjärjestelmä on kehittänyt omat arviointi- ja arvostelumenettelynsä, jonka tulokset ilmoitetaan koe-, testi- ja tenttinumeroina tai todistusarvosanoina ja kelpoisuustodistuksina.

Toisena, huomattavasti vaikeammin arvioitavana osana ovat koulutuksen viivästetyt tulokset ts. vaikutukset, jotka näkyvät hyötynä sekä yksilölle että yhteiskunnalle: työllistettävyys, tulot, sosiaalinen asema ja liikkuvuus, yhteiskunnalliset osallistumisvalmiudet tai tuotannon ja tuottavuuden kasvu, vakaa yhteiskuntajärjestys, kansainvälinen kilpailukyky ja kansan sivistystason nousu.

Em. tekijäryhmät yhdistää loogisesti ja toiminnallisesti koulutusteknologia, johon kuuluvat $\mathrm{mm}$. opetussuunnitelmat, koulutuksen organisointi koulutusasteiksi ja -aloiksi, johtaminen ja hallinto, oheispalvelut (mm. opintososiaalinen toiminta) ja erilaiset opetus- ja informaatiotekniikat tarvittavine materiaaleineen. Viimeksi mainitut ovat olleet keskeisiä tekijöitä koulutuksen taloustieteelle, koska niitä on voitu säädellä kokeellisissa asetelmissa mm. kehitysmaiden koulutusta organisoitaessa. (Ks. esimerkiksi vertailuja eri etäopetustekniikkojen, kuten radio-, televisio- tai puhelinopetuksen, ja perinteisen kontaktiopetuksen hyötysuhteiden välillä: Wagner 1982; Lockheed \& Verspoor 1990.)

\section{Tehokkuus ja vaikuttavuus}

Koulutuksen kannattavuutta arvioitaessa joudutaan käyttämään käsitteitä sisäinen ja ulkoinen tebokkuus ja vaikuttavuus. Eri yhteyksissä tutkijat ovat käyttäneet niitä (ja lisäksi termejä tekninen ja taloudellinen tehokkuus) tavalla, joka ei ole yhtenäinen.

Esimerkiksi seuraava jäsentely (ks. Lockheed \& Hanushek 1987, Tsang 1988) tuo käsitteiden käyttöön kurinalaisuutta. Kun panostekijät mitataan rahassa, tutkijat suosittavat termiä tehokkuus, ei-rahallisten panostekijöiden ollessa kysymyksessä puhutaan vaikuttavuudesta. Rahalliset tuotokset taas ovat ulkoisia ja ei-rahalliset sisäisiä.

Sisäistä tehokkuutta mitataan kustannus/vaikuttavuusanalyysein, ja se siis paranee, kun tavoitteiden suuntaista kasvatuksellista tuotosta 
nostetaan entisellä panoksella. Ulkoinen tehokkuus ilmaisee investointien tuottavuuden, ja sitä mitataan kustannus/byöty -analyysilla. Kysymyksessä on vertailu koulutusinvestointien ja muiden investointien tuottavuuden välillä: kannattaako sijoittaa koulutukseen vai tuottaako sijoitus muualla paremmin.

Sisäinen vaikuttavuus antaa mitan tekniselle tebokkuudelle: kiintein ja ennalta määrätyin voimavaroin tuotetaan maksimaalinen koulutustuotos (vaikkapa tutkintoja tai opintoviikkoja). Teknistä tehottomuutta esiintyy siis silloin, kun osa voimavaroista on alikäytössä. Sisäistä vaikuttavuutta voidaan näin lisätä ilman lisäresursseja olemassaolevien käyttöä tehostamalla.

Taloudellisesta tebokkuudesta puhutaan silloin, kun määrätyllä hinta- ja teknologiatasolla voidaan entisellä panosmäärällä nostaa vaikuttavuutta muuttamalla eri panostekijöiden keskinäisiä suhteita ja niiden käyttöä tehostamalla.

Ja lopuksi: ulkoisessa vaikuttavuudessa pohditaan, miten opitut tiedot ja taidot muuntuvat taloudelliseksi hyödyksi yksilölle ja/tai yhteiskunnalle. Periaatteessa kaikki on siis suhteellisen yksinkertaista, mutta koulutuksen tehokkuuden ja vaikuttavuuden mittaamiseen tarkoitetut talous- ja käyttäytymistieteelliset välineet ovat kuitenkin vielä perin kehittymättömiä.

Tuotantofunktion määrittelemistä hankaloittaa lisäksi koulutuksen valikointifunktion sekoittuminen sen taloudelliseen funktioon. On ajateltavissa, että koulutusinstituutio suorittaa tehokkaasti työntekijöiden valikoinnin ja sijoittamisen (siivilöinnin) eri työasemiin työn hierarkiassa, mutta että koulutuksen tason nostamisella ei $s a$ turaatiopisteen saavuttamisen jälkeen enää olisi tuottavuutta lisäävää merkitystä (Lewis 1990). Koulutuksen ja ansioiden välinen korrelaatio selittyisi näin valintatehtävän onnistumisella eikä työntekijän kyvyillä.

\section{PELKKÄ KUSTANNUSTEN ARVIOINTI EI RIITÄ}

Taloudellisesti tiukkoina aikoina keskiöön nousee kustannusfunktion määrittäminen: miten minimikustannuksin saavutetaan haluttu tavoitetaso. Sisäistä ja ulkoista tehokkuuttahan nostetaan aina, kun kustannuksia onnistutaan laskemaan. Koulutuksen suurin kustannustekijä ovat henkilöstö- menot (60 - 90 prosenttia käyttökustannuksista) - onhan koulutus työvoimavaltaisin elinkeinoala jälkiteollisessa yhteiskunnassa. Ei siis ole ihme, että ankara henkilöstön supistamistavoite koskee myös kasvatussektoria peruskoulusta yliopistoon saakka, kun julkisia kustannuksia halutaan painaa alas.

Kustannusten minimoiminenkaan ei kuitenkaan ole aivan yksinkertainen asia. Erilaiset vastaukset kysymykseen, kuka kustannukset kattaa, tuottavat erilaiset toimintapolitiikat. Jos tarkoituksena on vain fiskaalinen julkisten menojen supistaminen, voidaan muita muutoksia tekemättä siirtää osa kustannuksista muille asianosaisille, perheille, opiskelijoille itselleen, työnantajille. Jos taas pyritään sosiaaliseen tehokkuuteen, kaikki kustannukset on (julkiset sekä suorat ja epäsuorat yksityiset) otettava mukaan tarkasteluun, jolloin käytössä olevien resurssien supistuessa toiminnan on tehostuttava tai tavoitteita on tarkistettava.

Toinen seikka, joka tekee suoran panosten supistamisen (juustohöyläperiaatteen) usein kyseenalaiseksi, on toiminnan volyymin merkityksen unohtaminen. Kustannusten mitaksi voidaan näet valita keskimääräiset (yksikkö)kustannukset tai rajakustannukset. Monasti resurssien supistamiseen reagoidaan toiminnan laajuutta vähentämällä (esimerkiksi pienentämällä opiskelijoiden sisäänottoa), mikä useimmiten merkitsee yksikkökustannusten nousua. Sen sijaan toiminnan laajentamisen vaatimat lisäresurssit monasti laskevat koko toiminnan yksikkökustannuksia. Tässä mielessä suuri on kaunista (vrt. käsite economics of scale).

Koon ekonomia näyttelee tärkeää osaa oppilaitoksen suuruuden optimoinnissa. Psacharopoulos (1982) ja Lee (1984) ovat osoittaneet, että yksikkökustannukset korkeakouluissa laskevat voimakkaasti aina 500 aloittavaan opiskelijaan saakka, kokoetu hidastuu mutta pysyy merkittävänä aina 10000 sisäänottoon saakka ja tasoittuu vasta sitten. Suomessa ei siis olisi yhtään (tai korkeintaan yksi) kooltaan optimaalista yliopistoa!

On myös muistettava, että koulutuksen voimavarojen allokointiprosessi on kaksivaiheinen: paljonko resursseja ohjataan koulutukseen ja miten ne käytetään koulutusektorin sisällä.

Edellisen päätöksen voi tehdä pelkästään kustannuksia tarkastelemalla. Nehän riippuvat tarjonta- ja kysyntätekijöistä. Tarjontaan eli budjettiosuuteen (julkisiin mahdollisuuksiin) vaikuttaa 
moni seikka: julkisten palvelujen arvostuserot (esimerkiksi koulutus vai sosiaalitoimi jne.), kansantalouden volyymi ja kasvunopeus, verokertymä ja verotusaste, inflaatioaste, työmarkkinasopimukset, ulkomaankaupan tase ja kansainvälinen koulutusapu. Kysyntään taas vaikuttavat muun muassa väestön määrä, sen lisääntyminen (tai väheneminen) ja ikäjakautuma, koulutuksen merkitys sosiaaliselle liikkuvuudelle ja tasa-arvolle (koulutuksen lupausarvo), teollisuuden ja tuotantoelämän valitsemat tuotantotekniikat, työllisyysaste, kansainvälinen työnjako, perheessä vallitsevat arvot ja muut yksilölliset tekijät jne. Näihin koulutusekonomisti ei juurikaan voi vaikuttaa. Jos taloudellinen ajattelu on ohjannut normatiivista päätöksentekoa voimavarojen allokoinnissa, se on pohjautunut kustannus/hyötyajatteluun eli vaihtoehtoisten investointien tuottoasteen vertailuun.

Sen sijaan koulutussektorin sisäinen voimavarojen käyttö on kiinteästi yhteydessä koulutusteknologiaan ja sen välityksellä koulutuksen tuotoksiin. Kaikkia tuotantofunktion parametreja on tarkasteltava samanaikaisesti. Omista päätöksistä riippuu toiminnan tekninen ja taloudellinen tehokkuus, joita tulisi siis seurata kustannus/vaikuttavuusanalyysein.

\section{TUOTANTOFUNKTIOKÄSITTEEN KÄYTTÖKELPOISUUDESTA}

Kaikkien koulutuksen taloustieteen analyysimenctelmien taustalla on siis olettamus tuotantofunktiosta. Induktivisen todellisuuskäsityksen mukaisesti tuotantofunktion olemassaoloa ei voida kyseenalaistaa empiirisin perustein (jos sitä ei tunneta, ei todista, että se ei olisi olemassa). Ongelmallinen se on siitä huolimatta. Ongelmallista on olettamus yhdestä tuotantofunktiosta. Koulutusta tapahtuu niin monenlaisessa ympäristössä ja kasvatustapahtumassa vuorovaikutuksen osapuolet ovat yksilöinä niin erilaisia, että tuotantofunktioita lieneekin monia.

Suunnittelun ja muutoksen hallinnan kannalta vieläkin ongelmallisempaa on, että funktiolausekkeen tekijöiden keskinäiset painosuhteet ja niiden vuorovaikutukset muuttuvat arvaamatta. Tuotantofunktiot eivät siis ole pysyviä ja kätkössä odottaen keksijäänsä (Monk 1989).

Hallinnon ohjaustehtävän kannalta olennaista onkin, ovatko tuotantofunktiot tietoisesti luotavissa ja muokattavissa. Missä määrin ne ovat tiedostetun tai tiedostamattoman päätöksenteon kohde? Kovin rohkealta ei tunnu väite, että erilaisten säästöpäätösten tekijöiden tai uudistusten esittäjien mielessä ei ole edes käynyt koko tuotantofunktion käsite.

Yritykset arvioida kasvatuksen tuotantofunktion parametreja eivät kuitenkaan ole olleet rohkaisevia. Esimerkiksi koulu- ja opettajatekijöiden merkitys oppimiselle on saanut epäjohdonmukaisia ja ristiriitaisia tulkintoja. Eräässä selvityksessä (Hanushek 1986) koottiin 147 tutkimuksen tulokset, joissa pyrittiin mittaamaan panostekijöiden vaikuttavuutta. Opettajan merkitystä käsittelevistä 106 tutkimuksesta 95:ssä riippuvuudet eivät olleet tilastollisesti merkitseviä ja loput 11 jakautuivat tasan positiivisen ja negatiivisen riippuvuuden kesken. Ainoa johdonmukainen tulos tutkimuksen tekijän mielestä onkin se, että mitään systemaattista riippuvuutta ei vallitse kasvatuksen panos- ja tuotosvariaabelien (esimerkiksi opiskelijaa kohti laskettujen kustannusten ja koulusaavutusten) välillä.

Jos systemaattisuudella tarkoitetaan mahdollisuutta yhden ainoan tuotantofunktiolausekkeen tuottamiseen, olen yhtä mieltä johtopäätöksen kanssa. Mutta systemaattisuus voi tarkoittaa myös sitä, että pyritään tunnistamaan vaihtelevat kehys-, ympäristö- ja yksilölliset tekijät, joiden vallitessa koulutus ja oppiminen tapahtuvat. Ei ihmisten ja organisaatioiden käyttäytyminen voi olla täysin ennalta-arvaamatonta.

Arviointimenetelmällä saadut epätyydyttävät tulokset ovatkin johdattaneet käyttämään tuotantofunktion käsitettä (silloin kun se siis tiedostetaan) eräänlaisena beuristisena ballinnollisten resurssointi- ja kohdentamispäätösten legitimointitekijänä. Omaksutaan ajatus, että tuotantofunktio on todellinen, mutta sitä ei tunneta, ja käytetään yleistä taloustieteellistä perustelua koulutustoimintojen resurssointiin, esimerkiksi kustannus/tehokkuus -ajattelua. Tämän yleisen kaavan soveltaminen saattaa kuitenkin johtaa onnettomiin juustohöyläpäätöksiin, joissa ei pyritäkään ymmärtämään supistettavien toimintojen erityisluonnetta ts. arvioimaan alan erityisiä tuotantofunktioita.

Taloustieteen teorioiden yhdistäminen kasvatustieteelliseen, psykologiseen ja sosiologiseen käsitteenmuodostukseen saattaa kuitenkin antaa uusia mahdollisuuksia kasvatuksen tuotantofunktion avaamiseen. Esimerkiksi kognitiivinen psykologia tarjoaa uusia mahdollisuuksia tuotostekijöiden määrittelemiseen korkeampina kognitiivisina 
oppimisen prosessitekijöinä. Samaten on hyödyllistä jakaa panostekijät koulutuksen infrastruktuurin mahdollistamiin "varustetekijöihin" (käytettävissä oleva aika, opettajankoulutuksen laatu, opetustilat, opintotuki ja muu oppilashuolto jne.) ja prosessitekijöihin eli välittömiin kasvatuspalveluihin (oppimateriaalin laatu, interaktiotapahtuman luonne, tukiopetus, evaluaatiotoiminta jne.).

Tavallaan kysymys on tuotantofunktion jakamisesta kahtia kasvatuksen ja koulutuksen tuotantofunktioon, jolloin edellinen on (taloustieteen näkökulmasta) jälkimmäisen funktio.

Aivan liian vähälle on jäänyt koulutuksen yksilöllisiä ja yhteiskunnallisia vaikutuksia tutkittaessa muodollisen koulutuksen aikaansaama yksilöllisen, yksilöittäin kasautuvan ja kollektiivisen oppimisen määrä ja laatu verrattuna epämuodolliseen ja muissa kasvattavissa organisaatioissa kuin koulussa tapahtuvaan oppimiseen.

Kasvatuksen tuotantofunktioiden salojen paljastaminen on edellytys sille, että muodollinen koulutus kykenee toteuttamaan ne sosiaaliset ja taloudelliset odotukset, jotka sille pitkälti uskon varassa on kohta 200 vuotta kohdistettu. Jos ja kun koulutus vaikuttaa yhteiskuntaan, se tekee sen vain yksilön oppimisen välityksellä. Loogiselta silloin tuntuu, että sisäisen ja teknisen tehokkuuden tutkimuksen on edellettävä ulkoisen vaikuttavuuden ja tehokkuuden tutkimusta.

Monet ristiriitaiset tutkimustulokset johtunevat siitä, että tuotostekijöinä on pidetty nimenomaan koulutustuotoksia (tutkintojen suorittaneiden absoluuttinen tai suhteellinen määrä koulutusasteittain, elinikäiset ansiot yksilöllä tai bruttokansantuote kansakunnalla, koulutuksen läpäisyaste jne). Koulutus ei kuitenkaan takaa oppimista. Kasvatuksen (oppimisen) tuotantofunktion ja sen avulla koulutuksen tuotantofunktion salojen paljastaminen on tehostettua tutkimusta vaativa kohde.

Aika olisi myös päättää tempoileva koulutuspolitiikka, jossa päättäjät vauraina aikoina vannovat koulutuksen siunauksellisuuden nimeen ja pitävät sitä keskeisenä investointitekijänä, mutta taloudellisesti tiukkoina aikoina tulkitsevat koulutuksen ikävänä kestokulutushyödykkeenä, jonka nautintaa tulee ankarasti vähentää.

Arkijärkeilykin olettaisi voimavarojen jakamisen tapahtuvan juuri päinvastoin. Haluttujen koulutus- ja oppimisvaikutusten aikaansaaminen vaatii pitkän ajan, ja panostekijöiden radikaali muuttuminen säteilee vaikutuksia pitkälle tulevaisuuteen.

Yleensäkin koulutuspoliittisen päätöksenteon tulisi aikaisempaa huolellisemmin perustua kustannustietoisuuteen. Tsang (1988) näkee seuraavat arviot tarpeelliseksi yhtä hyvin pienestä opetusuudistuksesta kuin laajasta järjestelmämuutoksesta päätettäessä: On arvioitava uudistuksen kokonais- tai laajentamisen marginaalikustannukset, varmistettava voimavarojen saatavuus ja riittävyys, arviotava myös pitkän aikavälin kustannusvaikutukset ja sovittava, miten kustannustaakka jaetaan intressiryhmien välillä. Kustannustietoisuus ja taloudellisten sekä toiminnallisten vaikutusten ottaminen huomioon organisaation tai yksilön toiminnassa ei millään lailla mitätöi tai aliarvosta kasvatuksen humanistista tai emansipatorista luonnetta.

\section{LÄHTEET}

Hanushek, E. 1986: The Economics of Schooling. Journal of Economic Literature 24, 1141-1177.

Lee, K. 1984: Further Evidence on Economics of Scale in Higher Education. Washington: The World Bank.

Levin, H. 1988: Cost- Effectiveness and Educational Policy. Educational Evaluation and Policy Analysis 10, 1, 51-69.

Lewis, D. 1990: Estimating the Economic Worth of a 5th-Year Licensure Program for Teachers. - Educational Evaluation and Policy Analysis 12, 1, 25-39.

Lockheed, M. \& Hanushek, E. 1987: Improving the Efficiency Education in Developing Countries. Washington: The World Bank.

Lockheed, M. \& Verspoor, A. 1990: Improving Primary Education in Developing Countries. Washigton: The World Bank.

Monk, D. 1989: The Education Production Function. Educational Evaluation and Policy Analysis 11, 1, 69-83.

Psacharopoulos, G. 1980: The Economics of Higher Education in Developing Countries. - Comparative Education Review 26, 2, 139-159.

Tsang, M. 1988: Cost Analysis for Educational Policymaking. BRIDGES 3, 1988.

Wagner, L. 1982: The Economics of Educational Media. London: Macmillan. 